\title{
Yabancı Dil Öğretiminde İthal ve Yerel Ders Kitaplarının Kullanımına İlişkin Öğretmen Görüşleri
}

\author{
Dr. Öğr. Üyesi Doğu Ataş \\ Hacettepe Üniversitesi, Eğitim Fakültesi \\ Yabancı Diller Ĕ̆itimi Bölümü \\ datas@hacettepe.edu.tr
}

\begin{abstract}
Öz
Ülkemizde yabancı dil derslerinde kullanılan ders kitaplarının bir kısmı ithal, bir kısmı ise Türkiye'de yazılan yerel ders kitaplarıdır. İthal ders kitapları standartlaştırılmış uluslararası ders kitapları olup, hazırlandıkları ülkeden farklı eğitim ilkelerine, öğretim yöntemlerine ve kültürel normlarına sahip olan birçok ülkeye de ihraç edilmektedirler. Buna karşın iyi kurgulanmış yerel ders kitapları ise yazıldığı ülkenin geleneksel öğretim ve öğrenme alışkanlıklarını, kültürel normlarını ve ihtiyaçlarını dikkate alınarak hazırlanan kitaplardır. Bu araştırmanın amacı, yabancı dil öğretmenlerinin ithal ve yerel ders kitapları hakkındaki görüşlerini inceleyerek, Türk öğrencisine yönelik tasarlanacak olan yerel yabancı dil ders kitaplarında dikkat edilmesi gereken ölçütleri tespit etmektir. Bu çalışmada nitel araştırma yöntemi kullanılmıştır. 2018-2019 eğitim-öğretim yılında yabancı dil öğretmenleriyle gerçekleştirilen araştırmada açık uçlu soru anketi kullanılarak veriler toplanmıştır. Anket yoluyla elde edilen veriler içerik analizi tekniği ile çözümlenmiştir. Çalışmada elde edilen veriler doğrultusunda araştırmaya katılan yabancı dil öğretmenlerinin Türkiye'de yabancı dil derslerinde kullanılan ithal ve yerel ders kitapları hakkındaki görüşleri tespit edilmiştir. Bu bulgular doğrultusunda araştırmaya katılan öğretmenlerin oldukça büyük bir kısmının mevcut yerel yabancı dil ders kitaplarını yetersiz buldukları ve dolayısıyla ithal ders kitaplarını kullandıkları ortaya konulmuştur. Ayrıca, Türk öğrencisine yönelik yerel yabancı dil ders kitaplarının geliştirilmesinde dikkat edilmesi gereken ölçütler belirlenmiştir.
\end{abstract}

Anahtar Kelimeler: Yabancı dil ders kitabı, ithal ders kitabı, yerel ders kitabı, nitel araştırma, içerik analizi.

\section{Teachers' Opinions on the Use of Global and Local Coursebooks in Foreign Language Teaching}

\footnotetext{
Abstract

Some of the coursebooks used in foreign language courses in our country are global and imported while others are local coursebooks and written in Turkey. Global coursebooks, which are standardized and international, are exported to many countries that have different educational principles, teaching methods and cultural norms from the country in which they are prepared. By contrast, well-designed local coursebooks are books prepared considering 
the traditional teaching and learning habits, cultural norms and needs of the country in which they are written. The aim of this research is to determine the criteria to be considered in the local foreign language coursebooks that will be designed for the Turkish students by examining the opinions of foreign language teachers regarding the global and local coursebooks. Qualitative research method was used in this study. In the research conducted with foreign language teachers in the 2018-2019 academic year, data were collected by using an open-ended questionnaire. That data obtained through that questionnaire were analysed by the content analysis method. In accordance with the data obtained from the study, opinions of the foreign language teachers, who participated in the questionnaire, have been identified regarding the global and local coursebooks that are used in foreign language classes in Turkey. With these findings, it was revealed that a great majority of the participants found the current local foreign language coursebooks insufficient, and therefore used global coursebooks. Furthermore, the criteria to be considered in the development of local foreign language coursebooks for Turkish students have been determined.

Keywords: Foreign language coursebook, global coursebook, local coursebook, qualitative research, content analysis. 


\section{GİRIŞ}

Yabancı dil ders kitapları, yetişkinlere, gençlere ve çocuklara yönelik olarak kurgulanmaktadır. Bu kurguda önemli bir özellik kitabın hangi hedef grup için yazıldı̆̆ıyla ilgilidir. Kitaplar belirli bir hedef gruba değil de genel olarak farklı ülkelerden söz konusu yabancı dili öğrenmek isteyenlere göre yazılmaktadır. Örneğin yetişkinlere uygun yazılan bir yabancı dil ders kitabı ile bir Fransız, bir İtalyan, bir Türk veya bir Koreli o yabancı dili öğrenebilir. Bu amaçla yazılan kitaplar genellikle ithal ders kitaplarıdır ve özel olarak belirli bir gruba yönelik olarak yazılmamışlardır.

Yerel ders kitapları ise, belirli bir ülkenin belirli bir yöresinde yabancı dil öğrenenlerin isteyenlerin ihtiyaçları, kültürel özellikleri ve öğretim programları dikkate alınarak yazılmış kitaplardır ve genellikle o ülkenin yazarları veya ilgili makamlarının oluşturduğu komisyonlar tarafından hazırlanmaktadırlar.

Neuner'e (1995, s. 292) göre, ders kitabında yer alan malzemeler öğretim ve öğrenim sürecinin özelliklerine göre hazırlanmalıdır. Bu özellikler, başta kaynak dil olmak üzere, kültürel özellikler, yaşa özgü öğrenme ve yaşam deneyimleri gibi hedef gruba özgü faktörler olarak sıralanabilir. Çalışmada ayrıca, ders kitaplarının belirli bir hedef grubuna göre tasarlanması gerektiği vurgulanmaktadır. Genç'e (2012, s. 224-225) göre yerel ders kitapları, hedef öğrencilerin öğrenme alışkanlıkları ve ihtiyaçları dikkate alınarak bir ülke veya bir bölge için hazırlanan ders kitapları olarak açıklanmaktadır. Buna karşın, ithal ders kitapları, geniş bir kitleye yönelik olarak hazırlanıp, hedef gruplar arasındaki farklılıkları göz önünde bulundurmazlar. Yerelleştirilmiş ders kitapları ise ithal kitapların hedef grup için uyarlanarak yerelleştirilmiş biçimleridir. Yabancı dil öğretimi için tasarlanan ithal ders kitaplarının, Türkiye'de öğrencinin öğrenme koşullarını göz önünde bulundurarak yerelleştirilmesinin dersin verimliliği üzerinde olumsuz etkileri olduğu tartışılmaktadır. Buna rağmen ithal yabancı dil ders kitaplarının yerelleştirilmesi sıklıkla gündeme gelmektedir (bkz. Ünver ve Genç, 2009, s. 321-322).

İthal ders kitapları incelendiğinde, standartlaştııılmış yapıdaki uluslararası ders kitaplarının geliştirilmesinde, günümüzde yabancı dil öğretiminde kullanılan yaklaşımların, bölgeye özgü öğretim ve öğrenme koşullarını, eski yaklaşımlara kıyasla daha fazla dikkate aldıkları tespit edilmiştir. Ancak, bir süredir yabancı dil öğretiminde, yerel ders malzemelerine de ihtiyaç olduğu sıkça tartışılan diğer bir konudur. Ders kitabı setinde yer alan malzemeleri geliştirirken sadece konu içeriğine ve iletişim durumlarının seçimine dikkat etmek yeterli olmayacaktır. Bu süreçte dikkat edilmesi gereken iki önemli nokta öğretim konsepti ve yöntemsel yaklaşımların hedef gruba uygun olmasıdır. İletişimsel yönteme veya kültürler arası yaklaşıma dayalı yabancı dil dersleri için geliştirilen ithal ders kitabı seti, dünyanın farklı yerlerindeki tamamen farklı öğretim ve öğrenme geleneklerine sahip olan ülkelere ihraç edilmektedirler. Ders kitabı setinde yer alan malzemeler, daha çok konu içeriği seçimi ve belirli toplumlarda bazı durumlarda ortaya çıan iletişim durumlarının seçimine dikkat edilerek geliştirilmektedirler. Yerel ders kitabı setlerine ihtiyaç duyulmasının nedenleri, bu malzemelerin o toplumun kültürel normlarını, geleneklerini, eğitim ilkelerini, geleneksel öğretim ve öğrenme alışkanlıklarını dikkate alınarak hazırlanıyor olmalarıdır. Yerel ders kitap setleri doğrudan leksikal, fonetik ve morfolojik alanda karşılaştırmaları içerebilir, ayrıca öğretenlerin ve öğrenenlerin özel ihtiyaçlarını ve hedeflerini büyük ölçüde dikkate alabilirler (bkz. Storch, 2008, s. 283). Yukarıda ders kitabı ve ders kitabı seti olarak iki ayrı ifade geçmektedir. Ders kitabı, kendi 
içinde tamamlanmış belirli öğretici bir çizgi ve yönteme sahip olan basılı bir eserdir. $\mathrm{Bu}$ kitaplarda öğretme ve öğrenme için ihtiyaç duyulan tüm yardımcı malzemeler metinler, alıştırmalar, dil bilgisi, sözlük, vb. iki kitap kapağı arasında yer almaktadır. Ders kitabı seti ise öğrenci ders kitabı, alıştırma kitabı, öğretmen kılavuz kitabı, sözlük, dil bilgisi kitabı, ek metinler, işitsel medya ses bandı, kaset, çevrimiçi dinleme metinleri, görsel medya duvar resimleri, resim kartları, tepegöz için slaytlar, filmler, videokasetler, çevrimiçi görsel malzemeler, vb. gibi birçok farklı öğretim malzemelerinden oluşmaktadır (bkz. Neuner, 2007, s. 399). Çalışmanın devamında ders kitabı veya ders kitapları ifadeleri aynı zamanda ders kitabı seti yerine kullanılacaktır.

Ülkemiz okullarında yabancı dil derslerinde okutulan ders kitaplarının bir kısmı ithal, bir kısmı ise komisyonlar tarafından Türkiye'de yazılan veya Türkiye'deki yayınevlerine yazdırılan yerel ders kitaplarıdır. Yabancı dil öğretiminde hangi ders kitabının okutulacağı yönündeki karar, Millî Eğitim Bakanlığına (MEB) bağlı Talim ve Terbiye Kurulu Dairesi Başkanlığı tarafından verilmektedir. Her öğretim yılı öncesinde hangi sınıf için hangi ders kitabının okutulacağı belirlenmekte ve kurumun resmi yayın organı olan Tebliğler Dergisinde ilan edilmektedir. 2019-2020 Eğitim-Öğretim yılında ilkokul, ortaokul ve liselerde okutulacak Almanca, Fransızca ve İngilizce ders kitapları ve ders kitabı yerine kullanılacak eğitim aracı ve öğretim materyalleri listesi Tebliğler Dergisinin Ocak ayında yayınlanmışır. Bu dergide yayınlananlar arasından uygun olan kitaplar, okul veya kurum yöneticileri tarafından Millî Eğitim Bakanlığı Bilişim Sistemleri (MEBBi̇S) Kitap Seçim Modülü kullanılarak seçilmektedir (bkz. 2019-2020 Eğitim-Öğretim Yılında Okutulacak Ders Kitapları, 2019). Fakat ders kitaplarının seçiminde bazı okulların özellikle özel okulların farklı kaygılar nedeniyle ithal kitapları tercih ettikleri de bilinmektedir. Aslında Milli Eğitim ilke ve kurallarına, dersin genel amaç ve hedeflerine uygunluğunun dikkate alındığı yerel ders kitapları da ithal yabancı dil öğretim ders kitapları gibi Diller için Avrupa Ortak Öneriler Çerçevesi kataloğuna göre yazılmış ders kitaplarıdır. Bu katalog, A1 ve A2 düzeyleri temel kullanıcı, B1 ve B2 düzeyleri bağımsız kullanıcı, C1 ve C2 düzeyleri usta kullanıcı olarak belirlenerek bir standart getirilmeye çalışılmıştır (bkz. Genç, 2012, s. 197). O halde ülkemizde ithal ders kitaplarının tercih edilmesi örneğin A1 seviyesine uygun içeriğe sahip ithal bir ders kitabını yerel ders kitabından farklı kılan ve öğrencilerin kullanımına sunan özelliklerin neler olduğu konusu irdelenmelidir. Bu inceleme yerel yabancı dil öğretimi ders kitabı geliştirme sürecine ve üretime katkı sağlayabilir.

Cumhuriyetin ilk yıllarından itibaren yabancı dil derslerinde yerel ders kitaplarının yazılması ve okutulması yönünde çabalar sarf edilmiştir. Millî Eğitim Bakanlığı Ücretsiz Ders Kitabı Temini Projesi adı altında 2003-2004 Eğitim-Öğretim yılında ilk defa ilköğretim öğrencilerine 81.834.281 adet kitap dağıtılmış ve bu kitaplar için 157.523.013 TL harcanmıştır. 2006-2007 Eğitim-Öğretim yılında ise ilk kez ortaöğretim öğrencilerine 142.307 .609 adet kitap dağıtılmış ve bu kitaplar için 267.583.942 TL ödenmiştir. Yukarıda belirtilen tarihlerden itibaren günümüze kadar hemen hemen her yıl ilköğretim ve ortaöğretim öğrencilerine ücretsiz ders kitabı dağıtımı sağlanmıştır (bkz. Dinçer, 2012, s. 15). 2003 yılından 2018 yılına kadar toplam 2 milyar 850 milyon 288 bin 456 kitap ilköğretim ve ortaöğretim öğrencilerine ücretsiz dağıtılmış ve ücretsiz ders kitabı temini için toplam 5 milyar 506 milyon 519 bin 749 lira ödeme yapılmıştır. 2019 yılı için ise ortaöğretim öğrencilerine ücretsiz ders kitabı dağıtılması amacıyla öngörülen bütçe 477 milyon 500 bin lira, ilköğretim öğrencilerine ücretsiz olarak dağıtılacak ders kitapları için de 881 milyon lira kaynak tahsisi öngörülmüştür (bkz. Bakan Selçuk, TBMM Plan ve Bütçe Komisyonunda Sunum Yaptı, 
2018). Fakat ders kitaplarının ücretsiz dağıtılması ithal ders kitaplarının tercih edilmesini engellememiş ve 2000'li yıllardan günümüze yabancı dil öğretimi ders kitapları pazarında ithal ders kitapları da yaygın olarak satılmıs ve bazı okullarda okutulmuştur ve halen okutulmaktadır. Genç (2002), kitap seçiminde büyük oranda etkili olan yabancı dil öğretmenlerinin ders kitaplarını seçerken öğretim planı, öğrenciye ve öğrenme/öğretme ortamına uygunluk vs. gibi ölçütlerin önemine işaret etmektedir. İthal ders kitabını seçme eğiliminde olanların ise ücretsiz dağıtılan yerel ders kitaplarının öğretim programına uygun olmaması, basım kalitesinin, görselliğinin, albenisinin yetersizliği gibi nedenlerle hareket ettiği varsayılmaktadır. Fakat üzerinde durulması gereken asıl önemli nokta, ülkemizdeki öğrenme başarısının tartışıldığı yabancı dil derslerinde ithal, yerel veya her ikisinin birlikte kullanımı olmak üzere hangi tür ders kitaplarının, Türk öğrencisinin ihtiyacını karşılayacağı ve öğretimde başarıya götüren yolda katkısıyla ilgilidir (bkz. Genç ve Ataş, 2017, s. 19).

Bu çalışmada, yabancı dil öğretmenlerinin ithal yabancı dil öğretim ders kitaplarını seçme veya tercih etmeleri varsayımından hareket edilerek bunun nedenleri araştırılacak ve elde edilecek verilerin yerel ders kitaplarının geliştirilmesinde dikkate alınacak ölçütlere eklenip eklenemeyeceği belirlenecektir. Bu doğrultudaki araştırma soruları şunlardır:

1. Öğretmen görüşlerine göre yerel ders kitaplarının tercih edilmeme gerekçeleri nelerdir?

2. Öğretmen görüşlerine göre yerel ders kitaplarının tercih edilme gerekçeleri nelerdir?

3. Öğretmen görüşlerine göre ithal ders kitaplarının tercih edilme gerekçeleri nelerdir?

Bu çalışmada nitel araştırma yöntemi kullanılmıştır. Anket yoluyla toplanan veriler, nitel veri analiz programı MAXQDA'a aktarılarak kodlama yapılmıştır. Mayring (2013) tarafından önerilen nitel içerik analizi, tümevarımcı kategori oluşturma teknikleri kullanılarak verilerin kodlanması için temel ve alt kategoriler oluşturulmuş ve analiz edilmiştir.

Araştırmaya katılan öğretmen görüşlerinden elde edilen veriler doğrultusunda yabancı dil derslerinde ithal ders kitaplarının tercih edilme gerekçeleri ve yerel ders kitaplarının tercih edilmeme gerekçeleri ortaya konulmuştur.

\section{YÖNTEM}

\section{Araştırma Modeli}

$\mathrm{Bu}$ araştırmada içerik analizi türlerinden tümevarımcı kategori oluşturma tekniği kullanılmıştır. İçerik analizinin amacı, iletişime yönelik materyallerin sistematik olarak işlenmesidir. Tümevarımcı kategori oluşturma tekniği ise yazılı materyallerden kategorilerin geliştirilmesi için, nitel içerik analizi kapsamında tümevarımcı kategori oluşturmayı temel alan sistematik indirgeme sürecine dayalı bir tekniktir (Mayring, 2013, s. 472). Buradan hareketle bu araştırmada ilk ve ortaöğretim kurumlarında görev yapan yabancı dil öğretmeni görüşlerine dayalı olarak ithal ve yerel yabancı dil öğretimi ders kitaplarının tercih gerekçelerinin belirlenmesi amacıyla nitel içerik analizi yapılmıştır.

\section{Evren ve Örneklem}

Araştırmanın evreni, 2018-2019 eğitim-öğretim yılında Ankara'nın Çankaya ilçesinde bulunan özel ortaöğretim kurumlarındaki 8 öğretmen, özel ilköğretim kurumlarındaki 3 öğretmen ve kamu ortaöğretim kurumlarında görev yapan 2 öğretmen olmak üzere toplamda 13 öğretmenden oluşturmaktadır. Öğretmenlerin isimleri yerine anket sıra 
numaraları verilerek araştırmaya katılan kişilerin kimlikleri saklı tutulmuştur. Araştırmanın örneklemi Ankara ilinin Çankaya ilçesinden basit rastgele örnekleme (simple random sampling) yöntemi ile belirlenmiştir.

Çalışma örneklemine katılan 13 öğretmenin 10'u kadın (77\%), 3'ü erkektir (33\%). Öğretmenlerin kıdem dağılımları incelendiğinde ise, 10'u 1-5 yıl, 2'si 6-19 yıl ve 1'i 11 yıl ve üzerinde kıdeme sahiptir. Araştırmaya katılan öğretmenlerin Lisansüstü eğitimleri bulunmamaktadır ve katılanların tümü Eğitim Fakültesi lisans mezunlarıdır. Öğretmenlerin $10^{\prime}$ u Almanca öğretmeni olarak çalışmaktadır ve Almanca öğretmenlerinin 5'i özel ortaöğretim kurumunda, 2'si kamu ortaöğretim kurumunda ve diğer 3 kişi ise özel ilköğretim kurumunda görev yapmaktadır. Araştırmaya katılan 3 kişi ise İngilizce öğretmeni olarak özel ortaöğretim kurumunda çalışmaktadır.

\section{Veri Toplama Aracı}

Araştırmaya ilişkin verileri elde etmek için araştırmacı tarafından geliştirilen açık uçlu soru anketi kullanılmıştır. Bu anketin geliştirilmesi için öncelikle alan yazın taraması yapılmıştır. Geliştirilen sorular yabancı diller eğitimi ve istatistik bölümlerinde görev yapmakta olan iki öğretim üyesinin uzman görüşüne sunulmuştur. Uzmanların önerileri doğrultusunda anket formunda düzenlemeler yapılmıştır. Anket formunun ön uygulaması üç yabancı dil öğretmeniyle yapılmış ve ön uygulamanın analizleri yapıldıktan sonra son şekli verilmiştir. Böylece bir açık uçlu, bir kapalı uçlu sorudan ve kişisel bilgiler formundan oluşan veri toplama aracı oluşturulmuştur. Kişisel bilgi formu, yabancı dil öğretmenlerinin cinsiyet, eğitim durumu, mesleki kıdem, çalıştığı kurum, eğitimini verdiği yabancı dil ve son olarak araştırmanın yapıldığı eğitim-öğretim yılında kaçıncı sınıfa/sınıflara yabancı dil dersi verdiklerini içeren 6 sorudan oluşmaktadır. Kapalı uçlu soru öğretmenlerin yabancı dil derslerinde kullanmayı tercih ettiği ders kitap türüne yöneliktir. Açık uçlu soru ile ise, öğretmenlerin derslerinde kullandıkları ders kitaplarını neden tercih ettiklerini ayrıntılı olarak yazılı ifade etmeleri istenmektedir.

\section{Verilerin Analizi}

Anket çalışması, 2018-2019 öğretim yılının Mart-Nisan aylarında gerçekleştirilmiştir. Cevaplaması yaklaşık 30 dakika süren anketler, belirlenen okullarda araştırmacılar eşliğinde güvenli bir şekilde uygulanmıştır. Öğretmenlerin araştırmaya katılımı gönüllülük esasına dayalı olarak gerçekleştirilmiştir. Nitel veri setini oluşturan öğretmen görüşleri bilgisayar ortamına aktarılmıştır. Nitel verinin incelenmesinde, kodların, temel ve alt kategorilerin oluşturulması için Mayring (2013) tarafından önerilen nitel içerik analizi, tümevarımcı kategori oluşturma tekniği uygulanmıştır. Bu işlemde nitel veriler araştırmacı tarafından satır satır okunarak kodlanmış ve aynı işlem başka bir öğretim üyesi tarafından tekrarlanmıştır. Analiz sonunda oluşturulan kodlar karşılaştırılmış ve birbiriyle örtüşen kodlardan temel ve alt kategoriler oluşturulmuştur. Kodlama işlemini gerçekleştiren kişiler arasındaki güvenirlik katsayısını hesaplayabilmek için Miles ve Huberman (1994) tarafından geliştirilen formül [Görüş Birliği / (Görüş Birliği + Görüş Ayrıllğı) x 100] kullanılmış, güvenirlik katsayısı \%91 olarak hesaplanmış ve kodlamayı yapan kişiler arasındaki uyumun oldukça yüksek olduğu ortaya çıkmıştır. Nitel verilerin analizinde MAXQDA 11 programından yararlanılmıştır. Çalışmanın bulgular bölümünde öğretmen görüşlerinin bir kısmı alıntılanarak örnek veri olarak sunulmuştur. Sunulan alıntılarda içerik ve cümle yapısında hiçbir değişiklik yapılmadan birebir aktarılmıştır. Bulgular kısmında yer verilen alıntılarda, kısaltma yapılarak alıntı yapılan katılımcılara ilişkin bazı bilgilere de yer 
verilmiştir. Alıntılarda kullanılan kısaltmalar, anket sıra numarası $(1,2,3, \ldots)$, öğretmenin cinsiyeti (K: kadın, E: erkek), okul türü (KaO: kamu ortaöğretim kurumları, Özİ: özel ilköğretim kurumları, ÖzO: özel ortaöğretim kurumları) ve öğretmenin eğitim verdiği yabancı dil (ALM: Almanca ve İNG: İngilizce) şeklinde ifade edilmiştir. Örneğin: 1KÖzOALM olarak ifade edilen kişi için 1 rakamı anket sıra numarasını, K harfi kadın olduğunu, ÖzO harfleri özel ortaöğretim kurumlarında görev yaptığını ve ALM harfleri ise eğitim verdiği yabancı dilin Almanca olduğu anlamına gelmektedir. Bulgular kısmında yer verilen alıntılar araştırmacılar tarafından da yorumlanmıştır.

\section{BULGULAR}

Araştırmada öğretmen görüşlerine başvurularak yabancı dil öğretiminde ithal ve yerel ders kitaplarının tercih edilme nedenleri incelenmiştir. Bulgular kısmında sırasıyla üç araştırma sorusunun yanıtları ayrı ayrı değerlendirmiştir.

\section{Birinci Araştırma Sorusuna İlişkin Bulgular ve Yorum}

Çalışmanın birinci araştırma sorusuna cevap verebilmek amacıyla, içerik analizi sonucunda "yerel ders kitaplarını tercih etmemeye ilişkin gerekçeler" teması elde edilmiştir. $\mathrm{Bu}$ temanın elde edilmesinde "dilbilgisinin tümdengelim yöntemiyle verilmesi, dil öğretiminde geleneksel yöntemlerin kullanılması, telaffuzun doğru sağlanmaması, sözcük öğreniminin ezbere dayalı olması, iki dilin kullanılması, hedef dilin kültürel özelliklerini aktarmaması, kullanılan resimlerin gerçeği yansıtmaması, konuşulduğu ülkede kullanılan isimlere yer verilmemesi, yanlışlar içermesi (yazım, anlatım, noktalama yanlışı) ve konuşma becerisini geliştirmemesi" kodları etkili olmuştur. Tespit edilen kodlara ilişkin alıntıların bir kısmı örnek veri olarak aşağıda sunulmaktadır:

Yanlışlar içermesi (yazım, anlatım, noktalama yanlışı): “Pekiştirme olarak kullanılan çalışma kitapları öğrenilen bilgiyi öğrencilerin aktarması için sunulan bir gereçtir, fakat içerisinde yer alan alıştırmaların yanlış olması öğretmene güvenilirliği azaltmakla kalmayıp, belirsizliğe neden olacaktır. İncelemiş olduğum çoğu yerel ders kitabında, özellikle Milli Eğitim Bakanlığı'na bağlı olan okullarda kullanılan kitaplarda hem dilbilgisi yönünden, hem de iletişimsel hedef yönünden hatalar ve eksikler gözettim” (5KÖzİALM). “Günümüzde eğitim sektörü öyle bir hal aldı ki herkes yazdığı kitabın kalitesine değil de sadece kâr amacı güttüğü ek kazanç sağlamak amaçlı kitaplar sundukları için mecburen ithal ders kitaplarına yönelmek zorunda kalıyoruz yoksa beni çok mutlu ederdi yerel ders kitaplarının bilgi açısından hatasız olup kitaplarda çeşitli etkinliklere yer vermeleri" (2EÖzOALM). “Bizim Türkiye'de yapılan kitaplar hep hatta dolu” (4KÖzİALM).

Hedef dilin kültürel özelliklerini aktarmaması: "Bir dil bir insan düşüncesinde olduğum için, yeni bir öğrenirken o dilin; kültürünü, yaşam şartlarını, sosyal etkinliklerini ve o dilin milletine ait çoğu özelliği öğrencinin öğrenmesi gerektiği düşüncesindeyim. Bundan dolayı ise yerel ders kitaplarını bu hedeflere uygun bulmamaktayım" (5KÖzİALM). "Yabancı dil öğretimiyle ilgili ders kitaplarının amacı; iletişimsel yetiyi geliştirmek, dilin doğasına ve öğrenimine karşı bir farkındalık oluşturmak, yabancı kültürü iyice incelemek ve yabancı kültürdeki insanlara karşı olumlu tutumlar geliştirmek olarak sıralanmaktadır. Kullanılan yerel ders kitaplarında maalesef ki bu kriterlerin hepsi bulunmamaktadır. Yerel Almanca ders kitaplarında, yeterli şekilde Alman kültürü yansıtılamamaktadır, 
bunun yanı sıra geleneksel dil öğretme alışkanlıkları hala kullanılmaktadır" (8KÖzOALM).

Dil öğretiminde geleneksel yöntemlerin kullanılması: “(...) bunun yanı sıra geleneksel dil öğretme alışkanlıkları hala kullanılmaktadır. Günümüzde ise dil öğretimi daha çok iletişimsel yöntemlere dayanmaktadır. Öğrenci öğrendiği dili nasıl kullanacağını bilmelidir, ancak bu, yerel ders kitaplarında yeteri şekilde gösterilememektedir" (2KÖzOALM).

Kullanılan resimlerin öğrenciyi motive etmemesi: “Konuşmaya yönelik çalışmaların kullanılmaması ve orijinal resimlerin tercih edilmemesi öğrencilerin ilgisini çekmemektedir" (5KÖzİALM).

Telaffuzun doğru să̆lanmamasi: “Diyaloglarda ya da ses kayıtlarında konuşan kişiler anadil seviyesiyle Almanca konuşan insanlar ama bu doğru Almanca telaffuzu sağlamıyor. Bir konuşan "ch" telaffuzuna " $\mathrm{h}$ " kullanırken diğeri "ş" kullaniyor" (6EKaOALM).

Dilbilgisinin tümdengelim yöntemiyle verilmesi: “Beste Freunde kitabına nazaran gramer bilgileri yerel kitaplarımızda hemen veriliyor. Bir kutunun içerisinde sağda ya da solda görebilirsiniz. Bu da öğrencinin gramer bilgisine olan bağlılı̆̆ını artırıyor" (6EKaOALM).

Sözcük öğreniminin ezbere dayalı olması: "Fakat yerel kitaplarda birçok Türkçe sözcük yer almakta ve Almanca sözcüklerin bazıları okunduğu gibi Türkçe yazılmış ve bu akıl karıştırıcı olmaktadır, ezbere dayalı ve Türkçe mantık ile öğrenilmiş bir dilin doğru ve uzun vadeli bir öğrenme olmadığını düşünmekteyim” (5KÖzİALM).

İki dilin kullanılması: “Görev yapmakta olduğum özel okulda ve kurslarda tercihim her zaman ithal kitaplardan yana oldu ve 2 ylllı tecrübemde bunun herhangi bir dezavantajını görmedim. Aksine kitaplarda sadece yabancı dilin kullanılması öğrenme sürecini iyi yönde etkiledi" (5KÖzİALM).

Hedef dilin konuşulduğu ülkelerde kullanılan isimlere yer verilmemesi: "Almanca kitabın içinde Türkçe isimler var mesela yerler Türk yerleri bu bence aktif bir öğrenim olmuyor" (4KÖzİALM).

Konuşma becerisini geliştirmemesi: "Yabancı dil öğretimiyle ilgili ders kitaplarının amac1; iletişimsel yetiyi geliştirmek, dilin doğasına ve öğrenimine karşı bir farkındalık oluşturmak (...). Kullanılan yerel ders kitaplarında maalesef ki bu kriterlerin hepsi bulunmamaktadır” (8KÖzOALM). “Ama ne yazık ki yerel ders kitaplarında (şu ana kadar gördüğüm kadarıla) zor olan bir konuyu tamamen bir üniteye koyup onunla sadece tekrarlama yapılıyor. Hâlbuki her ünitenin bir iletişimsel konusunun olup, sınıfta bununla ilgili konuşabiliyor olmalıyız" (1KÖzOALM). “Konuşmaya yönelik çalışmaların kullanılmaması (...)" (5KÖZIALM).

Araştırmaya katılan altı (6) öğretmen yerel ders kitaplarını tercih etmeme nedenlerine yönelik açıklamalarda bulunmuşlardır. Bunlardan dört (4) yerel ders kitaplarını tercih etmeme gerekçelerini, çeşitli hatalar içermesi olarak belirtmişlerdir. Bu dört öğretmenin bir tanesi yerel ders kitaplarında öğrenilen bilgiyi pekiştirmek amacıyla sunulan alıştırmalarda hatalar bulunduğunu ifade etmektedir. Ayrıca aynı kişi yerel ders kitaplarında hem dilbilgisinde hem de konuşmaya dayalı alıştırmalarda hatalar tespit ettiğini vurgulamıştır. 
Bir (1) öğretmen ise, sunulan yerel ders kitaplarının içerik bakımından çok kaliteli olmadığını, kitapların daha çok kâr amaçlı üretildiklerini savunmuştur. Bir başka öğretmen ise, 2017-2018 döneminde kullandığı kitabın adını vererek, tespit ettiği hataları örnek olarak sunmuştur. Diğer bir öğretmen ise, Türkiye'de yazılan kitapların çok sayıda hatalar içerdiğini belirtmiştir. İki (2) öğretmen yerel ders kitaplarının hedef dilin kültürel özelliklerini aktarmaması gerekçesiyle tercih etmediklerini açıklamışlardır. Bu görüşte olan öğretmenlerden birisi yerel ders kitaplarının hedef dilin kültürel özelliklerine göre yazılmadığını da ek olarak ifade etmiştir. Diğer öğretmen ise, yerel Almanca ders kitaplarının yeterli şekilde Alman kültürünü yansıtmadığını belirtmiştir. Bir (1) öğretmen, yerel ders kitaplarının geleneksel dil öğretim yöntemlerine göre tasarlanması nedeniyle tercih etmediğini belirtmiştir. Başka bir (1) öğretmen, yerel ders kitaplarını tercih etmeme gerekçesi olarak kullanılan resimlerin öğrencileri motive etmediğini ifade etmiştir. Bir (1) öğretmen özellikle ses kayıtlarında Almanca telaffuzun doğru verilmemesi nedeniyle yerel ders kitaplarını tercih etmediğini belirtmiştir. Aynı kişi yerel ders kitaplarında dilbilgisinin tümdengelim yöntemiyle verilmesini bir başka gerekçe olarak sunmuştur. Bir (1) öğretmen ise, yerel ders kitaplarını tercih etmeme nedenlerinden birisinin bu tür kitaplarda sözcük öğreniminin ezbere dayalı olması olarak ifade etmiştir. Diğer gerekçesi ise, yerel ders kitaplarında ana dilin kullanılması olmuştur. Birinci gerekçesinde Almanca sözcüklerin bir kısmının okunduğu gibi Türkçe yazılarak sözcük öğreniminin öğrenci için uygun olmadığını belirtmiş̧ir. İkinci gerekçesinde ise, tecrübelerine dayanarak ders kitaplarında anadilin kullanılmasının öğrencilerini olumsuz etkilediğini açıklamıştır. Bir (1) öğretmen, yerel Almanca ders kitabında hedef dilin konuşulduğu ülkelerde kullanılan isimlere yer verilmemesinden dolayı tercih etmediğini gerekçe olarak sunmuştur. Üç (3) öğretmen, yerel yabancı dil öğretimi ders kitaplarının konuşma becerisini geliştirmediğini belirtmişlerdir. Bu görüşte olan öğretmenlerden birisi incelediği yerel ders kitaplarında bir ünitede yer alan konuyu pekiştirmek için konuşmaya dayalı alıştırmaların bulunmadığını eklemiştir. Ayrıca ders kitaplarında bu tür alıştırmalara yer verilmesi gerektiğini de vurgulamıştır.

\section{İkinci Araştırma Sorusuna İlişkin Bulgular ve Yorum}

Çalışmanın ikinci araştırma sorusunu yanıtlayabilmek için içerik analizinden "yerel ders kitaplarını tercih etmeye ilişkin gerekçeler" teması belirlenmiştir. Bu temanın oluşturulmasında "Millî Eğitim Bakanlığı tarafından belirlenmesi ve zümre kararı ile belirlenmesi" kodları etkili olmuştur. Tespit edilen kodlara ilişkin alıntılar aşağıda sunulmaktadır:

Millı̂ Ĕgitim Bakanlı̆̆ı tarafindan belirlenmesi: “MEB'de öğretmen olduğum için kurumlara gönderilen kitapların dışına çıkamıyorum. Tercih etme fırsatım olsaydı sırasıyla 1. yaş 2. metot. 3. öğrencilerin dikkatini çekme ve ilgi alanlarına inme 4 . bol resimli ve uzun olmayan diyaloglar 5.4 dil becerisine hitap eden kitaplar seçerdim. MEB özellikle içerisinde bulunduğumuz eğitim yılı içerisinde yabancı dil ders kitap kitaplarında büyük gelişimler sağladı. Kitaplar dört dil becerisine hitap etmekte ve içeriği öğrenciyi sıkmamakla birlikte öğrencilere etkin katılım olanağı sunmaktadır" (7EKaOALM).

Zümre kararı ile belirlenmesi: “Çalıştığım kurumda merkez kampüsün zümre kararıyla Einfach Deutsch adlı ders kitabını kullanmaktayız. Görseller açısından güzel düzenlenmiş olsa da alıştırma bölümlerini ve dinleme metinlerini yeterli bulmuyorum ve ekstra ithal ders kitaplarından yararlanarak alıştırma ve 
ödevlerle öğrenciye katkıda bulunmaya çalışıyorum. Tercih bana ait olsaydı ithal bir Almanca kitabını kullanmayı, konuların akışının ve alıştırmaların, dinleme metinlerinin daha iyi düzenlenmiş olması sebebiyle kullanmayı tercih ederdim. Devlet tarafından gönderilen Almanca ders kitapları ise müfredata uygun ancak konular çok hızlı pekiştirilmeden ve birbirine tam olarak koordineli gitmediği için kullanmayı tercih etmiyorum" (3KÖzOALM). "Çalıştığım kurumun belirlemiş olduğu kaynakçaları kullandığım için. Ama bence yabancı dil eğitiminde ana dili ülkeleri tarafından hazırlanmış kitaplar ders eğitim ve öğretiminde daha etkili oluyor" (10KÖzOİNG).

Araştırmaya katılan öğretmenlerden üçü (3), derslerinde yerel ders kitaplarını kullandıklarını belirtmişlerdir. Bir (1) öğretmen yabancı dil öğretiminde okutulacak kitapların Millı̂ Eğitim Bakanlığı tarafından belirlenmesi nedeniyle, yabancı dil öğretiminde yerel ders kitaplarını kullandığını açıklamıştır. Buna karşın tercihin kendisine bırakılması halinde, kitap seçimini belirli ölçütlere göre yapacağını belirtmiştir. Öğretmenin kitap seçim ölçütleri sırasıyla hedef grubun yaşı, kitapta dil öğretimi için belirlenen yöntemlerin ve konuların öğrenciye uygun olması, çok resim kullanılmış kısa diyalogların ve dört dil becerisine yönelik alıştırmaların bulunmasıdır. Ayrıca bu öğretmen, 2017-2018 öğretim yılında Millı̂ Eğitim Bakanlığı çatısı altında yazılan yabancı dil öğretimi ders kitaplarında büyük gelişmeler sağlandığını da belirtmiştir.

Araştırmaya katılan iki (2) öğretmen yerel ders kitaplarının yabancı dil öğretiminde kullanılma gerekçesi olarak zümre kararı ile belirlenmesini öne sürmüştür. Bu görüşte olan bir (1) öğretmen derste kullandıkları kitabın adını vererek, bu kitabın artı ve eksi yönlerini belirtmiştir. Derste kullanılan kitabın görsel açıdan iyi düzenlenmiş olduğunu, fakat kitabın alıştırmalarının ve dinleme metinlerinin yetersiz olduğunu açıklamıştır. Bundan dolayı derslerinde kullandığı yerel yabancı dil öğretimi ders kitabının yetersiz kaldı ̆̆ı yerlerde ithal bir yabancı dil öğretimi ders kitabını kullandığını belirtmiştir. Tercihin kendisine bırakılma durumunda, ithal yabancı dil öğretimi ders kitaplarını kullanacağını da açıklamıştır. Sırasıyla konuların, alıştırmaların ve dinleme metinlerinin yerel yabancı dil öğretimi ders kitaplarına kıyasla ithal yabancı dil öğretimi ders kitaplarında daha iyi düzenlenerek aktarıldığını ifade etmiştir. Bu kişi MEB tarafından yabancı dil öğretimi için belirlenen kitaplarının müfredata uygun olduğunu, ancak bu kitaplarda yer alan konular için yeterli düzeyde alıştırmaların bulunmadığını belirtmiştir. Bu nedenle konuların pekiştirilmediğini ve birbiriyle bağlantılı olmadığını eklemiştir. Dolayısıyla Almanca öğretimi için yerel ders kitaplarını tercih etmek istemediğini belirtmiştir. Diğer bir (1) öğretmen ise yazarın anadilinde yazılmış ders kitaplarının yabancı dil öğretiminde daha etkili olduğunu belirtmiştir.

\section{Üçüncü Araştırma Sorusuna İlişkin Bulgular ve Yorum}

Çalışmanın üçüncü araştırma sorusunu yanıtlayabilmek için "ithal ders kitaplarını tercih etmeye ilişkin gerekçeler" teması oluşturulmuştur. Bu tema kapsamında 15 kod belirlenmiştir. Bu kodlar "temel dil becerilerini içermesi, hedef dile ait kültürel öğelerin aktarılması, kurumun tercih etmesi, daha etkili olması, güncel olması, albenisinin ve basım kalitesinin daha yüksek olması, tek dilli olması/tek dillilik ilkesine uygunluğu, yazarın anadilinde yazılmış olması, konuşulduğu ülkede kullanılan isimlere vs. yer vermesi, dikkat çekici etkinliklere yer vermesi, teknoloji destekli kurgulanması, dilbilgisini tümevarım yöntemiyle vermesi, dilbilgisinin ön planda olmaması ve konu akışının-alıştırmaların- 
dinleme metinlerinin daha iyi olması" olarak tespit edilmiştir. Üçüncü temanın birinci kodu olan "temel dil becerilerini içermesi" koduyla ilgili tespit edilen alt kodlar ise şunlardır: "Okuma becerisiyle ilgili alıştırmaların çok olması, konuşma becerisiyle ilgili alıştırmaların çok olması, dinleme becerisiyle ilgili alıştırmaların çok olması ve konuşma becerisinin ön planda tutulması". Tespit edilen alt kodlarla ile ilgili bazı alıntılar aşağıda verilmektedir:

\begin{abstract}
Okuma becerisiyle ilgili alıştırmaların çok olması / Konuşma becerisiyle ilgili alıştırmaların çok olması: "İthal kitaplarda yerel kitaplara göre dilbilgisi öğretiminden ziyade konuşma, dinleme ve okuduğunu anlama yetisini geliştirmeye yönelik çalışmalar yoğun olarak bulunmaktadır" (8KÖzOALM).

Dinleme becerisiyle ilgili alıştırmaların çok olması: "İthal kitaplarımız zaten oldukça güncel ve dinleme yapma şansımız ders içinde daha çok" (12KÖzOALM).

Konuşma becerisinin ön planda tutulması: “Neden ithal kitap aslında birçok nedenleri var mesela ben ilkokul bölümünde Almanca Öğretmenliği yapıyorum ve ilkokula en uygun konuşmaya yönelik olarak eğlenceli gramerini arka planda veren oda az bir şekilde (...) Kommunikativ yönüne buna önem veriyorlar kullandığım kitapta. Bizim hedefimizde zaten bunu çocuklara verebilmek grameri saklı olarak aktarmak oda yaptığımız etkinlikler ile veya oyun veya şarkılarla" (4KÖż̇ALM).
\end{abstract}

Araştırmaya katılan öğretmenlerden ikisi (2), ithal ders kitaplarında konuşma ve okuma becerisine yönelik alıştırmaların oldukça yoğun olduğunu, üç (3) öğretmen ise, dinleme becerisi ile ilgili araştırmaların sıkça ele alındığını ifade etmişlerdir. Ayrıca araştırmaya katılan iki (2) öğretmen, ithal ders kitaplarında konuşma becerisinin ön planda olduğunu ve dilbilgisinin arka planda verildiğini belirtilmiştir. Bu sıralanan gerekçelerden dolayı yukarıda görüşleri dile getirilen öğretmenler yerel yabancı dil öğretimi ders kitapları yerine ithal ders kitaplarını tercih ettiklerini açıklamışlardır.

Üçüncü temanın ikinci kodu "hedef dile ait kültürel öğelerin aktarılması" ile ilgili olarak tespit edilen alıntılar aşağıda sunulmaktadır:

Hedef dile ait kültürel öğelerin aktarılması: “İsimler Almanca yerler Almanca yemekler şehirler falan böyle daha birçok örnek verebilirim. En azından çocuklar Almanca isimler, Almanca şehirler ve yemekler onların kültürünü görebiliyorlar" (4KÖzİALM). “Değişik kültürel öğeler içerirler, bu da öğrencinin derse merakını ve ilgisini artırı" (8KÖzOALM). "Farklı kültürleri anlatım yöntemini daha iyi buluyorum" (9KÖzOİNG). "Kitap içinde ki kısa videolar ve o videoları oynayan kişilerin Alman olması dile ve kültüre öğrencileri daha çok yaklaştırıyor. Bu da ders içi performansı iyi yönde etkilemektedir" (12KÖzOALM).

Araştırmaya katılan dört (4) öğretmen, ithal yabancı dil öğretimi ders kitaplarında, hedef dile ilişkin kültürel öğelerin aktarıldığını ifade etmişlerdir. Aynı zamanda bu dört (4) öğretmenden ikisi (2), hedef dile ait kültürel öğelerin derste aktarımının öğrencilerin ders içi performansını olumlu etkilediğini de eklemişlerdir.

Üçüncü temanın üçüncü kodu "kurumun tercih etmesi" ile ilgili olarak tespit edilen alıntılar aşağıda verilmektedir:

Kurumun tercih etmesi: “Çalıştığımın kurumun belirlemiş olduğu kaynakçaları kullandığım için" (10KÖzOING). "Genelde kurumumuz ithal ders kitaplarını tercih etmekte. Ama bu 2017-2018 eğitim ve öğretim yılında ortaya çıkan "Wie 
bitte" adlı Almanca ders kitaplarımız oldukça güncel ve içerik bakımından zengin" (12KÖzOALM). "Öncelikle belirtmek isterim ki, kitap seçme gibi bir şansım olmadı. Çalıştığım kurum kitap seçimini kendileri belirliyor. Çalıştığım okulda ithal ders kitapları kullanılıyor ve bu durum diğer yabancı dil ders kitaplarında da geçerli. Fakat tercih hakkı bana verilmiş olsaydı da muhtemelen ben de ithal ders kitabı tercih ederdim" (13KÖzİALM).

Araştırmaya katılan üç (3) öğretmen yabancı dil öğretiminde okutulacak kitapların kurumları tarafından belirlendiğini açıklamışlardır. Üç (3) öğretmenden biri (1) "Wie bitte" adlı yerel Almanca ders kitabının içeriğinin güncel ve kapsamlı olduğunu ifade etmiştir. Bu kişi bu ifadesi ile adı geçen yerel Almanca ders kitabının kullanımı hakkında olumlu düşüncesini yansıtmıştır. Buna karşın diğer öğretmen ise, ders kitabı tercih hakkı kendisine bırakılma durumunda, büyük ihtimalle çalıştığı kurumun verdiği karar gibi ithal yabancı dil öğretimi ders kitaplarını tercih edeceğini belirtmiştir.

Üçüncü temanın dördüncü kodu "daha etkili olması" ile ilgili olarak tespit edilen alıntı aşağıda verilmektedir:

Daha etkili olması: “Ama bence yabancı dil eğitiminde ana dili ülkeleri tarafından hazırlanmış kitaplar ders eğitim ve öğretiminde daha etkili oluyor" (10KÖzOİNG).

Yukarıdaki görüşe sahip olan öğretmen, ithal yabancı dil öğretimi ders kitaplarının yerel yabancı dil öğretimi ders kitaplarına göre yabancı dil eğitimi ve öğretiminde daha etkili olduğunu belirtmiştir. Bu nedenle, derslerinde ithal yabancı dil öğretimi ders kitaplarını kullandığını ifade etmiştir.

Üçüncü temanın beşinci kodu "güncel olması" ile ilgili olarak tespit edilen alıntılar aşağıda verilmektedir:

Güncel olması: "Daha güncel konulara değiniyor" (9KÖzOİNG). “Ayrıca ithal ders kitapları en az 2 seneye bir güncellendiği için hem konuları hem de içerisinde bulunan görsellikler cağımıza uygun olduğunu görmekteyim (...)" (1KÖzOALM). "Güvenilir, kaliteli, güncel ve dizaynları daha iyi ve dünyaca kabul edilmiş kitaplar olduğu için" (11KÖzOİNG). "İthal kitaplarımız zaten oldukça güncel ve dinleme yapma şansımız ders içinde daha çok" (12KÖzOALM).

Araştırmaya katılan öğretmenlerden dördü (4), ithal yabancı dil öğretimi ders kitaplarının yerel yabancı dil öğretimi ders kitaplarına kıyasla daha güncel olmaları sebebiyle tercih ettiklerini belirtmişlerdir. Öğretmenlerden biri (1), yabancı dil ders kitaplarının iki senede bir güncellendiğini eklemiştir.

Üçüncü temanın altıncı kodu "albenisinin ve basım kalitesinin daha yüksek olması" ile ilgili olarak tespit edilen alıntılar aşağıda verilmektedir:

\begin{abstract}
Albenisinin ve basım kalitesinin daha yüksek olmast: "İthal kitaplar öğrenciler açısından daha albenili bulunmaktadırlar, çünkü görsel nitelikleri daha fazla ve öğrencilerin alıştıklarından daha farklıdır" (8KÖzOALM). (...) dizaynları daha iyi ve dünyaca kabul edilmiş kitaplar olduğu için" (11KÖzOİNG). “Ders kitaplarını karşılaştırdığımızda ithal kitaplarda verilen materyallerin ve etkinliklerin daha dikkat çekici ve başarılı olduğunu görüyoruz" (13KÖż̇ALM).
\end{abstract}

Yukarıdaki ifadeler incelendiğinde, üç (3) öğretmenin ithal yabancı dil öğretimi ders kitaplarını albenisinin ve basım kalitesinin yerellerine göre daha yüksek olmasından dolayı 
tercih ettikleri ortaya çıkmaktadır. Bu öğretmenlerden biri (1), ithal kitapların bu özelliğinden dolayı daha etkileyici ve başarılı olduğunu düşünmektedir.

Üçüncü temanın yedinci kodu "tek dilli olması/tek dillilik ilkesine uygun olması" ile ilgili olarak tespit edilen alıntılar aşağıda verilmektedir:

Tek dilli olması/tek dillilik ilkesine uygun olması: “Görev yapmakta olduğum özel okulda ve kurslarda tercihim her zaman ithal kitaplardan yana oldu ve 2 ylllık tecrübemde bunun herhangi bir dezavantajını görmedim. Aksine kitaplarda sadece yabancı dilin kullanılması öğrenme sürecini iyi yönde etkiledi. Fakat yerel kitaplarda birçok Türkçe sözcük yer almakta ve Almanca sözcüklerin bazıları okunduğu gibi Türkçe yazılmış ve bu akıl karıştırıcı olmaktadır, ezbere dayalı ve Türkçe mantık ile öğrenilmiş bir dilin doğru ve uzun vadeli bir öğrenme olmadığını düşünmekteyim” (5KÖzİALM). “Ayrıca ithal kitaplarda kelimelerin Türkçe karşılığını bulamazsınız bu da öğrenciyi araştırma yapmaya teşvik ediyor. Böylelikle öğrencinin daha aktif olduğu dersler işleniyor" (13KÖzİALM).

Araştırmaya katılan iki (2) öğretmen, tek dillilik ilkesine uygun hazırlanan yabancı dil öğretimi ders kitaplarının olumlu yönlere sahip olduğunu belirtmiştir. Öğretmenlerden biri (1), bu tür kitapların öğrenciyi araştırma yapmaya teşvik ettiğini ifade etmiştir. Diğer öğretmen ise kendi tecrübelerinden yola çıararak iki dilde hazırlanan yabancı dil kitaplarının dil öğrenimini olumsuz yönde etkilediğini açıklamıştır.

Üçüncü temanın sekizinci kodu "yazarın anadilinde yazılmış olması" ile ilgili olarak tespit edilen alıntılar aşağıda sunulmaktadır:

Yazarın anadilinde yazılmış olması: "İthal kitapların yazımı anadil üzerinden olduğu için öğrenme daha evrensel oluyor" (13KÖzİALM). "İthal ders kitabı seçmemdeki en büyük neden; kitap yazarlarının öğretmekte olduğumuz dilin yerinde doğup büyümüş olmalarıdır. Bunun en büyük avantajı o dile; anadili olarak sahip olmalarıdır. Böylelikle dili ikinci bir yabancı dil olarak öğrenmiş olan yazarlara nazaran, hata yapma olasılıklarının daha az olması da önemli bir etkendir" (5KÖzİALM).

Araştırmaya katılan iki (2) öğretmen derslerinde yazarın anadilinde yazılmış yabancı dil ders kitaplarını tercih ettiklerini belirtmişlerdir. Öğretmenlerden biri (1) ithal kitapların yerel kitaplara göre daha evrensel olduğunu vurgulamış ve ikinci öğretmen ise ithal yabancı dil öğretimi ders kitaplarında daha az hata görüldüğünü ifade etmiştir.

Üçüncü temanın dokuzuncu kodu "konuşulduğu ülkede kullanılan isimlere vs. yer vermesi" ile ilgili olarak tespit edilen aşağıdaki alıntıda öğretmenin önersi kültür aktarımı açısından önem taşımaktadır.

Konuşulduğu ülkede kullanılan isimlere vs. yer vermesi: “Almanca kitabın içinde Türkçe isimler var mesela yerler Türk yerleri bu bence aktif bir öğrenim olmuyor. Ama bizim Kitaplar Almanya'dan geldiği için Alman Yayınevi olduğu için çok daha verimli oluyor dersler. İsimler Almanca yerler Almanca yemekler şehirler falan böyle daha birçok örnek verebilirim. En azdın çocuklar Almanca isimler, Almanca şehirler ve yemekler onların kültürünü görebiliyorlar" (4KÖż̇ALM).

Yukarıda görüşü verilen bu öğretmen, kitaplarda kullanan isimlerin, yerlerin, şehirlerin ve yemeklerin hedef dilde verilmesi gerektiğini savunmuştur. Bu tür kitapların

SEFAD, 2020; (44): 309-328 
dersin verimliliğini artırdığını ifade etmiştir. Bundan dolayı derslerinde ithal yabancı dil ders kitaplarını kullandığını belirtmiştir.

Aşağıda üçüncü temanın onuncu kodu "dikkat çekici aktivitelere yer vermesi" ile ilgili olarak tespit edilen alıntıya yer verilmiştir:

Dikkat çekici aktivitelere yer vermesi: “Ders kitaplarını karşlaştırdığımızda ithal kitaplarda verilen materyallerin ve etkinliklerin daha dikkat çekici ve başarılı olduğunu görüyoruz" (13KÖzİALM). "Aktivite şansı daha fazla. Öğrencinin daha çok ilgisini çekiyor" (9KÖzOINNG).

Araştırmaya katılan iki (2) öğretmen ithal yabancı dil öğretimi ders kitaplarında dikkat çekici aktivitelere yer verildiğini ve bu kitapları tercih nedenlerinden birinin bu olduğunu dile getirmişlerdir. Bir (1) öğretmen aktivitelerin yerel ders kitaplarına kıyasla daha fazla olduğunu ifade etmiş; diğer iki (2) öğretmen ise, ithal yabancı dil öğretimi ders kitaplarında verilen aktivitelerin hem daha dikkat çekici hem de daha başarılı olduğunu vurgulamışlardır.

Üçüncü temanın on birinci kodu "güvenilir olması" ile ilgili olarak tespit edilen alıntılar aşağıda verilmektedir:

Güvenilir olmast: “Güvenilir, kaliteli (...) dünyaca kabul edilmiş kitaplar olduğu için" (11KÖzOİNG). "Çünkü ithal ders kitaplarında hata oranı daha az" (13KÖzİALM). “(...) en önemlisi Almancayı tam ve yanlışsız bir şekilde aktariyor" (4KÖzİALM).

Araştırmaya katılan üç (3) öğretmen ithal kitaplarını daha güvenilir bulduklarını ve bu nedenle derslerinde tercih ettiklerini belirtmişlerdir. İki (2) öğretmen ise, ithal kitapların neredeyse hiç hata içermediğini vurgulamıştır.

Aşağıda üçüncü temanın on ikinci kodu "teknoloji destekli kurgulanması" ile ilgili olarak tespit edilen alıntılara yer verilmektedir.

Teknoloji destekli kurgulanması: “Akıllı tahta uyumlu olan yerel ders kitaplarında kitabı sadece pdf olarak görebiliyoruz. Fakat ithal kitapların akıllı tahta uyumlarının uygulamalı ve animasyonlarının zengin olduğunu görebiliyoruz" (13KÖzİALM). “Hallo Anna serilerini kullanıyorum. İnanılmaz materyalleri çok olan CD'den tutun çalışma materyalleri sonra akılı tahta için tasarlanan hazır yansıtması için kitap ve flash kartlar çok verimli ve öğretici bir kitap olduğu için bu kitabı çok seviyorum ve öğrencilerden de çok olumlu dönüşler alıyorum" (4KÖzİALM). “Öğrencilerin, heyecan ile beklediği en önemli an ise, ders kitaplarının içerisinde konuyla ilgili mutlaka hazırlanmış video, şarkı veya oyundur" (1KÖzOALM). "Kitap içinde ki kısa videolar (...). Bu da ders içi performansı iyi yönde etkilemektedir" (12KÖzOALM).

Araştırmaya katılan dört (4) öğretmen için ders kitaplarının teknoloji destekli kurgulanması önemlidir. İki (2) öğretmen yukarıda bahsi geçen konsepte göre hazırlanmış olan kitapların öğrencilerin ders içi performansını pozitif yönde etkilediğini açılamıştır. Bu araştırmacılar örnek olarak bu tür ithal yabancı dil öğretimi ders kitaplarının animasyonlar, videolar ve şarkılar içerdiğini ve hatta akıllı tahta ile uyumlu uygulamalarının bulunduğunu içerdiği belirtmişlerdir. 
Üçüncü temanın on üçüncü kodu "dilbilgisinin tümevarım yöntemiyle verilmesi" ile ilgili olarak tespit edilen aşağıdaki alıntılar aslında öğretmenlerin sürekli dile getirdiği konuların da başında gelmektedir:

Dilbilgisinin tümevarım yöntemiyle vermesi: “Neden ithal kitap aslında birçok nedenleri var mesela ben ilkokul bölümünde Almanca Öğretmenliği yapıyorum ve ilkokula en uygun konuşmaya yönelik olarak eğlenceli gramerini arka planda veren oda az bir şekilde Hallo Anna serilerini kullanıyorum. (...) Kommunikativ yönüne buna önem veriyorlar kullandığım kitapta. Bizim hedefimizde zaten bunu çocuklara verebilmek grameri saklı olarak aktarmak oda yaptığımız etkinlikler ile veya oyun veya şarkılarla" (4KÖzİALM). “Langenscheid ve Hueber tarafından hazırlanan kitapları kullanmaktayım ve kullanmamın en büyük sebebi de içerisinde hem iletişimsel becerileri hem de dilbilgisi becerisinin bir ünite içerisinde harmanlanmış şekilde verilmesidir. Bunu açacak olursak; ünitelerin başından son sayfasına kadar her şey iletişimsel görünse de içerisinde yeni dilbilgisi konusu ve eski dilbilgisi konusunu tekrarlayan cümleler bulunmaktadır. Bu da dersi hem iletişimsel konuya göre işlemememize yarıyor ve hem de biz, öğrencilerle bu konu hakkında konuşurken, öğrenciler farkında olmadan hem eski dilbilgisi konusu hatırlamış hem de yeni bir dilbilgisi konusu öğrenmiş oluyor. Ünitelerin sonunda ise, genellikle dilbilgisi konusunu açıklayan bir sayfa bulunur" (1KÖzOALM).

Araştırmaya katılan iki (2) öğretmen derslerinde okuttukları ithal yabancı dil öğretimi ders kitaplarında dilbilgisinin tümevarım yöntemiyle verildiğini ve böylece iletişimsel becerilerin ön planda tutulduğunu açıklamışlardır. Bu öğretmenler ithal kitapları tercih etme nedenlerinin bu olduğunu söylemektedirler. Öğretmenler dilbilgisi ile konuşma yönelimlerinin başarılı birşekilde ve birlikte sunulduğunu ifade etmektedirler. Üçüncü temanın on dördüncü kodu "dilbilgisinin ön planda olmaması" ile ilgili olarak tespit edilen aşağıdaki alıntıda da dilbilgisinin ön planda tutulmadığı; buna karşın konuşma, dinleme ve okuduğunu anlama becerisinin geliştirilmesine daha çok önem verildiği vurgulanmaktadır.

Dilbilgisinin ön planda olmaması: “İthal kitaplarda yerel kitaplara göre dilbilgisi öğretiminden ziyade konuşma, dinleme ve okuduğunu anlama yetisini geliştirmeye yönelik çalışmalar yoğun olarak bulunmaktadır” (8KÖzOALM).

Üçüncü temanın on beşinci kodu "konu akışının-alıştırmaların-dinleme metinlerinin daha iyi olması" ile ilgili olarak tespit edilen aşağıdaki alıntıda da ithal yabancı dil öğretimi ders kitaplarında konu akışı, alıştırmalar ve dinleme metinlerinin daha iyi işlenmesi nedeniyle tercih edildiği öne sürülmektedir:

Konu akışının-alıştırmaların-dinleme metinlerinin daha iyi olması: "Tercih bana ait olsaydı ithal bir Almanca kitabını kullanmayı, konuların akışının ve alıştırmaların, dinleme metinlerinin daha iyi düzenlenmiş olması sebebiyle kullanmayı tercih ederdim" (3KÖzOALM).

Genel olarak öğretmen görüşleri incelenerek değerlendirildiğinde, aslında görüşlerin sadece ithal ve yerel ders kitaplarının seçilmesi ve tercih edilmesiyle sınırlı kalmadığı; öğretmenlerin sınıf içi deneyimlerinden hareketle ülkemizde yabancı dil öğretimine yönelik görüşlerini ilettikleri anlaşılmaktadır.

SEFAD, 2020; (44): 309-328 


\section{SONUÇ}

Öğretmen görüşlerinden elde edilen veriler işığında, araştırmaya katılan öğretmenlerin büyük çoğunluğunun yabancı dil öğretiminde yerel yabancı dil ders kitapları yerine ithal yabancı dil ders kitaplarını tercih ettikleri tespit edilmiştir. Bu duruma yol açan nedenler arasında, yerel yabancı dil ders kitaplarının kurgulanmasında geleneksel yöntemlerden etkilenmek, hedef dilin kültürel özelliklerinin aktarılmasında yaşanan güçlükler, sözlü iletişim becerisini geliştirecek etkinliklerin yetersiz oluşu ve yazım, dilbilgisi, içerik vb. hataların bulunması sayılabilir.

Derslerinde yerel yabancı dil öğretim ders kitaplarını kullandıklarını belirten öğretmenlerin söz konusu ders kitaplarını kullanmalarına gerekçe olarak Millî Eğitim Bakanlığı kararlarını göstermişlerdir. İthal yabancı dil öğretim ders kitaplarını tercih eden öğretmenler de gerekçelerini kitapların basım kalitesi, albenisi, güncelliği, teknoloji destekli oluşuna ve özellikle çalıştıkları kurumlar tarafından tercih edilmesine bağlamaktadırlar. Bu nedenler dişında kitaplarda hedef dilin konuşulduğu kültürlerin aktarılması, tek dillilik ilkesine uygun olması, anadilli yazarlar tarafından yazılmış olması, ilginç ve öğrenciyi motive eden aktivitelere yer vermesi ve yazım, dilbilgisi vs. hatalarıyla karşılaşılmaması sayllabilir. Türk öğretmenlerin dinleme, okuma ve konuşma gibi dil becerilerini ön planda tutan ve bu doğrultuda çok alıştırma ve etkinlik sunan ders kitaplarını tercih ettikleri de anlaşılmaktadır. Öğretmenler, artık dilbilgisinin etkisindeki bir kurguyla sunulan ders kitaplarını okutmak istememekte ve öğrencilerinde dil becerileri geliştirmek istemektedir.

Yukarıda yer verilen çalışma sonuçlarından yola çıkarak aşağıdaki öneriler geliştirilmiştir:

Yerel yabancı dil ders kitapları öğrencilerin yaşı, dil seviyesi, ihtiyaç ve ilgi alanı gibi belirli standartlara dayalı ölçütlere göre ve ders kitabı alanında uzman kişiler tarafından hazırlanmalıdır. Çağımızda yabancı dilin neden öğrenilmesi/öğretilmesi gerektiği konusu öğrencilerle paylaşılmalı ve onların ilgi ve ihtiyaçları doğrultusunda öğretim malzemesi geliştirilmeye özen gösterilmelidir. Özellikle öğrencilerin temel dil becerilerini geliştirmelerine yönelik kurgulanacak yerel yabancı dil öğretimi ders kitaplarında iletişim ortamları ve kültürlerarası anlayışı yaratabilen içeriklere yer verilmelidir. Yaş grubuna uygun çeşitli etkinliklere, kazanımlara uygun alıştırmalara yer verilmelidir. Yerel yabancı dil öğretim ders kitapları albenisi, basım/yayın kalitesi, görselliği ile öğrencileri motive edecek şekilde tasarlanmalıdır. Günümüzde teknoloji desteği olmayan öğretim malzemesinden bahsetmek oldukça zordur ve hedef grubun teknoloji becerisini de değerlendireceği eğitim ortamlarının yaratılmasına yönelik ders kitapları da geliştirilmelidir. Güncel bilgi ve becerilerle donatılmış ders kitaplarının geliştirilmesi aşamasında ülkemizdeki eğitime yön veren Millî Eğitim Bakanlığının ders kitapları geliştirme ilke ve kuralları dikkate alınmalıdır.

\section{SUMMARY}

When the imported coursebooks are examined, it has been found that the approaches used in foreign language teaching today consider the region-specific teaching and learning conditions more than the old approaches in the development of standardized global textbooks. However, another issue that has been frequently discussed is the need for local course materials in foreign language teaching. While developing the materials in the coursebook set, it will not be adequate to pay attention only to the subject content and the choice of communication situations. Two crucial points to be considered in this process are 
the teaching concept, and methodological approaches suitable for the target group. The imported coursebook sets for foreign language classes, based on communicative method or intercultural approach, are exported to countries in different parts of the world with completely different teaching and learning traditions. The materials and contents in these coursebook sets are developed by recognizing the communication situations that arise in fixed situations in certain societies. The reason for this need is that these materials are prepared by appraising the cultural norms, traditions, educational principles, traditional teaching and learning habits of that particular society. Local coursebook sets could include direct comparisons in the lexical, phonetic and morphological fields, as well as largely regarding the specific needs and goals of teachers and learners (Storch, 2008, p. 283).

Some of the coursebooks used in foreign language courses in our country are imported while some others are local coursebooks that are written in Turkey by commissions or publishing houses. The decision on which coursebook to be taught in foreign language teaching is made by the Board of Education under the Ministry of National Education (MEB). However, it is known that some schools, especially the private ones, opt for imported books due to different concerns in the selection of coursebooks. The local coursebooks, which are aligned with the principles and rules of National Education and the general goals and objectives of the course, are coursebooks written according to the Common European Framework for Languages, just like the imported foreign language teaching coursebooks. In this Framework, A1 and A2 levels are determined as basic users, B1 and B2 levels as independent users, C1 and C2 levels as proficient users to establish a standard (Genç, 2012, p. 197). Therefore, the preference of the imported coursebooks in our country should be examined especially in terms of what makes an imported coursebook suitable for A1 level students rather than the local coursebook.

In this research, the reasons why foreign language teachers choose or prefer imported foreign language teaching coursebooks will be examined, and it will be determined whether the obtained data could be added to the criteria to in the development of local coursebooks. The research questions are as follows:

1. What are the reasons for not choosing the local coursebooks according to teachers' opinions?

2. What are the reasons for preferring the local coursebooks according to teachers' opinions?

3. What are the reasons for preferring the imported coursebooks according to teachers' opinions?

The aim of this research is to determine the criteria to be considered in the local foreign language coursebooks that will be designed for the Turkish students by examining the opinions of foreign language teachers regarding the imported and local coursebooks.

Qualitative research method was used in this research. The data obtained through questionnaire were coded by qualitative data analysis program MAXQDA. By using qualitative content analysis and inductive categorization techniques proposed by Mayring (2013), basic and subcategories were created and analysed for data coding.

The universe of the research consists of 13 teachers in total, including eight teachers in private secondary education institutions in Çankaya district of Ankara, three teachers in private primary education institutions, and two teachers working in public secondary education institutions in the 2018-2019 academic year. The sample of the research was determined by simple random sampling method from Çankaya district of Ankara. 
In the research, the reasons for choosing imported and local coursebooks in foreign language teaching were examined by referring to teachers' opinions. In the findings section, the responses of three research questions were evaluated separately.

In order to answer the first research question of the research, the theme of "reasons not to prefer local coursebooks" was obtained as a result of the content analysis. In the acquisition of this theme, "giving grammar by deductive method, using traditional methods in language teaching, providing pronunciation incorrectly, learning vocabulary by memorization, use of two languages, not reflecting the cultural characteristics of the target language correctly, not including the names used in the country in which target language is spoken, containing mistakes (spelling, wording, punctuation), and not improving speaking skills" codes were effective.

In order to answer the second research question, the theme of "the reasons for choosing local coursebooks" was determined from the content analysis. The codes "determined by the Ministry of National Education, and determined by the decision of the committee" were effective in the creation of this theme.

In order to answer the third research question, the theme of "the reasons for choosing imported coursebooks" was created. 15 codes were determined within the scope of this theme. These codes include "having basic language skills, transferring of cultural elements of the target language, preference of the institution, being more effective and up-to-date, having higher appeal and printing quality, being monolingual/conforming to principle of monolingualism, being written in the native speaker of the language, including the names used in the country in which target language is spoken, including striking activities, being supported by technology, teaching grammar with inductive method, grammar not being in the foreground, and having better flow of subject-exercises-listening texts". The sub-code "including basic language skills", which is the first code of the third theme, is as follows: "The abundance of exercises related to reading, speaking and listening skills, and the prioritization of speaking skill".

In the light of the data obtained from teachers' opinions, it was determined that the majority of the teachers participating in the study preferred the imported foreign language coursebooks instead of local foreign language coursebooks in foreign language teaching. Among the reasons leading to this situation include being influenced by traditional methods in the local coursebooks, difficulties in conveying the cultural features of the target language, insufficient activities to improve speaking skills, and having spelling, grammar, content mistakes.

The teachers, who used the local coursebooks in their classes, indicated the decisions of the Ministry of National Education as the reason. The teachers, who preferred the imported coursebooks, attribute their decision to the publication quality, appeal, up-todateness and the technology support of the books, and especially the preference by the institutions they work with. Other reasons may include transferring of cultural elements of the target language, conforming to principle of monolingualism, being written in the native speaker of the language, having interesting and motivating activities, containing no spelling, grammar, etc. mistakes. It is understood that Turkish teachers prefer coursebooks that prioritize language skills such as listening, reading and speaking, and offer copious exercises 
accordingly. Teachers no longer want to teach coursebooks based heavily on grammar and want to improve their students' language skills.

Based on the research results, the following recommendations have been made:

The local coursebooks should be prepared by experts in the field according to criteria based on certain standards such as students' age, language level, needs and interests. Why a foreign language should be learned/taught in this era should be shared with students and teaching materials should be developed in line with their interests and needs. Especially, in the local coursebooks that will be designed to develop students' basic language skills should include content that can create communication environments and intercultural understanding. Various activities suitable for the age group and exercises based on the acquisitions should be included. The local coursebooks should be designed to motivate students with their appeal, print/publication quality, and visuality. Today, it is very difficult to talk about teaching materials without technology support, and coursebooks should also be developed to create educational environments where the target group will evaluate the technology skills. During the development of coursebooks equipped with up-to-date knowledge and skills, the principles and rules of the Ministry of National Education, which guides education in our country, should be taken into consideration.

\section{Makale Bilgileri}

Etik Kurul Kararı:

Katılımcı Rızası:

Mali Destek:

Çıkar Çatışması:

Telif Haklart:

Article Information
Araştırmanın veri toplama süreci 2020 yılından önce gerçekleştiği için Etik Kurul Kararından muaftır.

Araştırmaya katılanlara çalışmanın amacı ifade edilerek rızaları alınmıştır.

Çalışma için herhangi bir kurum ve projeden mali destek alınmamıştır.

Çalışmada kişiler ve kurumlar arası çıkar çatışması bulunmamaktadir.

Çalışmada telif hakkına sebep olacak bir materyal kullanılmamıştır.

\footnotetext{
Ethics Committee Approval: Since the data for the research were gathered before 2020, it is exempt from the Ethics Committee Approval.

Informed Consent: The purpose of the study is explained to the particants and their informed consent was obtained.

Financial Support: The study received no financial support from any institution or project.

Conflict of Interest: $\quad$ The authors declare that declare no conflict of interest.

Copyrights:

No material subject to copyright is included.
} 


\section{KAYNAKÇA}

2019-2020 Eğitim-Öğretim Yılında Okutulacak Ders Kitapları. (2019, 18 Şubat). Tebliğler Dergisi. $\quad$ Erişim adresi: http://tebligler.meb.gov.tr/index.php/tuemsayilar/viewcategory/87-2019.

Bakan Selçuk, TBMM Plan ve Bütçe Komisyonunda Sunum Yaptı. (2018, 7 Kasım). Erişim adresi: https://www.meb.gov.tr/bakan-selcuk-tbmm-plan-ve-butce-komisyonundasunum-yapti/haber/17391/tr.

Dinçer, Ö. (2012, 16 Aralık). 2013 Yılı Bütçe Sunuşu TBMM Genel Kurulu. Erişim adresi:https://sgb.meb.gov.tr/meb_iys_dosyalar/2012_12/25034222_2013_butce_sunusu. pdf.

Genç, A. \& Ataş, D. (2017, Ekim). Local or Imported?: Foreign Language Course Book Selection at Schools in Turkey [ÖZ]. 2nd International Conference on Best Practices and Innovations in Education presented paper, Dokuz Eylül University, Izmir.

Genç, A. \& Ünver, Ş. (2012). Türkiye' de geçmişten günümüze Almanca öğretimi için yazılan ders kitaplarındaki metinlerin incelenmesi. Eğitim ve Bilim Dergisi, 37, 163, 67-80.

Genç, A. (2002). İlk- ve ortaöğretim okullarında yabancı dil ders kitabı seçimi. Hacettepe Üniversitesi Ĕ̆itim Fakültesi Dergisi, 22, 74-81.

Genç, A. (2012). Wörterbuch Pädagogik - Ĕ̆itim Sözlüğü. Ankara: Hacettepe Yayıncllık \& Kitapçılık Ltd Sti.

Mayring, P. (2013). Qualitative Inhaltsanalyse. In U. Flick, E. von Kardorff und I. Steinke (Hrsg.). Qualitative Forschung: Ein Handbuch (10. Auflage), 468-475. Reinbek bei Hamburg: Rowohlt Taschenbuch Verlag.

Miles, M. B. \& Huberman, A. M. (1994). Qualitative data analysis: An expanded sourcebook. California: Sage Publications.

Neuner, G. (1995). Lehrwerke. In: Karl-Richard Bausch, Herbert Christ und Hans-Jürgen Krumm (Hg.). Handbuch Fremdsprachenunterricht, 3. Auflage (292 - 295). Tübingen und Basel: A. Francke Verlag.

Neuner, G. (2007). Lehrwerke. In: Karl-Richard Bausch, Herbert Christ und Hans-Jürgen Krumm (Hg.). Handbuch Fremdsprachenunterricht (399 - 402). Tübingen und Basel: A. Francke Verlag.

Storch, G. (2008). Deutsch als Fremdsprache - Eine Didaktik. Paderborn: Wilhelm Fink GmbH \& Co. Verlags-KG.

Ünver, Ş. \& Genç, A. (2009). Passwort Deutsch adlı Almanca ders kitabının Türkiye baskısının incelenmesi. Selçuk Üniversitesi Edebiyat Fakültesi Dergisi (SEFAD), 21, 321333. 